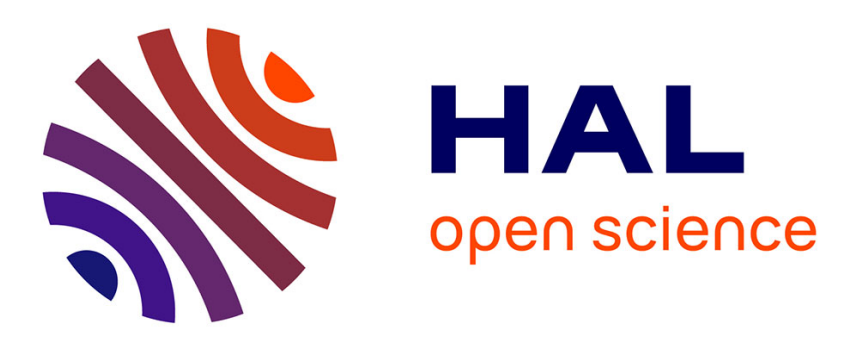

\title{
The effect of metals and cyanide on fertilization in rainbow trout (Salmo gairdneri)
}

\author{
Roland Billard, P Roubaud
}

\section{To cite this version:}

Roland Billard, P Roubaud. The effect of metals and cyanide on fertilization in rainbow trout (Salmo gairdneri). Water Research, 1985, 19 (2), pp.209-214. 10.1016/0043-1354(85)90202-7 . hal-01600850

\section{HAL Id: hal-01600850 \\ https://hal.science/hal-01600850}

Submitted on 2 Jun 2020

HAL is a multi-disciplinary open access archive for the deposit and dissemination of scientific research documents, whether they are published or not. The documents may come from teaching and research institutions in France or abroad, or from public or private research centers.
L'archive ouverte pluridisciplinaire HAL, est destinée au dépôt et à la diffusion de documents scientifiques de niveau recherche, publiés ou non, émanant des établissements d'enseignement et de recherche français ou étrangers, des laboratoires publics ou privés.

\section{다(1)(2)}

Distributed under a Creative Commons Attribution - ShareAlike| 4.0 International 


\title{
THE EFFECT OF METALS AND CYANIDE ON FERTILIZATION IN RAINBOW TROUT (SALMO GAIRDNERI)
}

\author{
R. BILlLARD and P. Roubatid \\ I.N.R.A., Laboratoire "de Physiologie des Poissons and Station Centrale de Physiologie Animale, 78350 \\ Jouy-en-Josas and 35042 Rennes Cedex, France
}

(Received May 1984)

\begin{abstract}
This paper reports a study testing the effects of several heavy nietals and cyanide on fertilization in rainbow trout. Two tests were carried out.

(1) The gametes were exposed independently for $40 \mathrm{~min}$ to a test chemical added into diluents. The

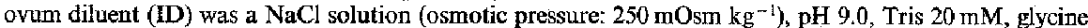
$50 \mathrm{mM}$. The spermatozoa were diluted at $10^{-1}$ and $10^{-2}$ and the same difuent with $\mathrm{K}^{+}$added; they were immobile in this diluent (CD). Insemination was carried out after the gametes had been washed.

(2) Ova and spermatozoa were mixed together in ID containing one of the chemicals to be tested (insemination test). In test 1 in which gametes were exposed over an extended time, the chemicals were only very slightly toxic to ova compared to sperm. Iron became toxic for ova at a concentration of $0.073 \mathrm{mg} \mathrm{l}^{-1}$ and the toxic thresholds of the other products were higher than $1 \mathrm{mg}^{-1}$. The chemicals had a more marked toxic effect on sperm diluted at $10^{-2}$ in the following decreasing order (in mg $1^{-1}$ ): chromium 0.005 , iron 0.005 , cyanide 1 , zine 20 . Insemination sometimes revealed lower thresholds of toxicity: chromium 0.005 , iron 0.08 , cyanide 0.001 , mercury $>1$. Copper had a favorable effect on fertilization. The tests, and particularly the insemination test, could be used to monitor the toxic effect of chemical on a stage of the life-cycle of fish which has been little studied up to now.
\end{abstract}

Many toxicity tests have been used to estimate the effects of pollutants on fish and to determine the factors of water quality (McKim et al., 1976; EIFAC, 1975). These tests, applied at various stages of the life cycle of fish, have shown that the carly developmental stages (embryonic and early juvenile: McKim, 1977) are the most sensitive to toxic products. Gametogenesis, an even earlier stage, has also proven sensitive to temperature variations and micropollutants, thus implicating gamete survival and fertilization (Billard, 1978; Billard et al., 1978; Billard and Gillet, 1981; Jaoul and Roubaud, 1982; Gillet and Roubaud, 1984). The present paper reports a study using gametes and their fertilization to estimate the toxicity of several metals and of cyanide incorporated into preservation and insemination diluents.

\section{MATERIAL AND METHODS}

The gametes were taken from the stock of brood rainbow trout at the laboratory at Jouy-en-Josas between November and January during the period of ovulation and spermiation; water temperature varied between 8 and $12^{\circ} \mathrm{C}$ during that period. Female brood fish were examined at least once a week to detect ovulation. Ova from several females were pooled before the experiment.

The method we used to estimate the toxicity of the products was to incorporate the one to be tested into (1) a diluent to be mixed with the gametes for $40 \mathrm{~min}$ (gamete survival test) or (2) a dilueat (ID) to be used for artificial insemination. The ovum survival test employed a simple solution of $\mathrm{NaCl}$ dissolved in distilled water (ID) (osmotic pressure: $250 \mathrm{mOsm} \quad \mathrm{kg}^{-1} ; \mathrm{pH} \quad 9.0$; Tris buffer $0.02 \mathrm{M}+$ glycine $0.05 \mathrm{M}$ ) (Billard, 1977) in which ova nor- mally survive for several hours. Such a diluent cannot be used for the sperm survival test because the spermatozoa become motile when diluted and only survive for several minutes. However, sperm motility can be inhibited in salmonids by adding $\mathrm{KCl}\left(30^{-} \mathrm{mM}\right)$ to the $\mathrm{ID}$; a conservation diluent (CD) was thus developed (Billard and Jalabert, 1974) in which the spermatozoa remain immotile. For the gamete insemination test, the gametes were mixed directly in the $\mathrm{ID}$ at $10 \pm 1^{\circ} \mathrm{C}$. The following products were incorporated into the diluents: $\mathrm{CuSO}_{4} \cdot 5 \mathrm{H}_{2} \mathrm{O}$ (Prolabo) $\mathrm{Cr}_{2}\left(\mathrm{SP}_{4}\right)_{3} \cdot 8 \mathrm{H}_{2} \mathrm{O}$ (Merck), $\mathrm{ZnSO}_{4} \cdot 7 \mathrm{H}_{2} \mathrm{O}$ (Prolabo), $\mathrm{HgCl}_{2}$ (Merck), $\mathrm{FeCl}_{2} \cdot 4 \mathrm{H}_{2} \mathrm{O}$ (Prolabo), $\mathrm{KCN}$ (Merck). We used concentrations ranging between 0.0004 and $100 \mathrm{mg} 1^{-1}$ of metal or cyanide jons; dikuents only were given to the control fish. After dilition, product solubility was measured by flame spectrophotometry after filtering by assaying the amounts in solution. All the products were totally solubilized except iron, of which $0.005,0.08,0.73$ and $1.13 \mathrm{mg} \mathrm{l}^{-1}$ were found in solution for $1,5,30$ and $100 \mathrm{mg} \mathrm{l}^{-1}$, respectively, introduced into the diluent.

Sperm, diluted at CD rates of $10^{-1}$ and $10^{-2}(1 \mathrm{ml}$ and $0.1 \mathrm{ml}$ of sperm diluted in $10 \mathrm{ml}$ of $\mathrm{CD}$ ) was left standing $40 \mathrm{~min}$ before it was centrifuged for $10 \mathrm{~min}$ at $1800 \mathrm{~g}$. The supernatant was discarded and replaced by fresh $\mathrm{CD}$. The spermatozoa were put back into suspension and the mixture used to inseminate lots of about $150-200$ ova each, pre viously diluted in $10 \mathrm{ml}$ of $\mathrm{m}$ (double dilution technique: Billard and Jalabert, 1974). The spermatozoa were activated in these conditions. The ova, divided into lots of about $150-200$ each, were mixed with $10 \mathrm{ml}$ of $\mathrm{ID}$ containing metals in solution or not (experimental lots and controls) and were left standing for $40 \mathrm{~min}$. The liquid was then discarded and replaced by fresh ID and insemination was carried out with intact spernatozoa at a dilution of $10^{-3}$. To test fertilization, we simply mixed the gametes with ID (about $150-200$ ova $+10 \mathrm{ml}$ of sperm: dilution of $10^{-3}$ ). In all cases, the mixture was left standing for 15 min after 


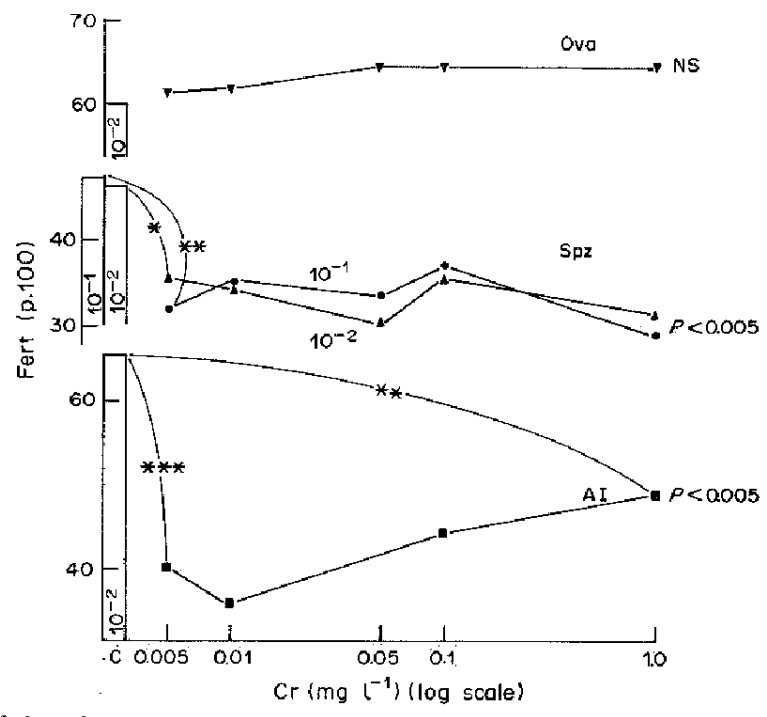

Fig. 1. Effect of chromium on rainbow trout gametes. Profiles of fertilization percentage (Fert. p. 100) after green eggs (ova) and spermatozoa (spz) were exposed independently or simultaneously (AI) to increasing concentrations of chromium in saline solutions. Insemination test: AI; $\mathrm{C}$ : control; gametes were exposed or insemination in diluent only at dilution rates of $10^{-2}$ and $10^{-1} . P$ values are given for comparison between dose by variance analysis. Comparison between controls and some experimental values are made with $\chi^{2}$ test; ${ }^{* *} P<0.01,{ }^{*} P<0.05$; NS-non significant

insemination; the ova were rinsed and transferred into incubators for incubation at $10 \pm 1^{\circ} \mathrm{C}$ for 10 days. The eggs were then fixed in Stockard's solution and the percentage of eyed-eggs counted was an approximate measurement of the fertilization rate. Tests were made in duplicate.

Fertilization percentages resulting from a total treatment were compared using variance analysis after angular transformation. Two fertilization percentages were compared using the $x^{2}$ test (controls vs experimental).

\section{RESULTS}

The results are shown in Figs 1-6 and Table 1. For both dilution rates, the lowest concentration of chromium tested $\left(0.005 \mathrm{mg} \mathrm{l}^{-1}\right)$ was clearly toxic for spermatozoa (Fig. 1). The effect was seen again during fertilization. On the other hand, this metal seemed to have no effect on the ova up to concentrations of $1 \mathrm{mg} \mathrm{l}^{-1}$.

Iron in solution had an unfavorable effect on spermatozoa from concentrations of less than $0.005 \mathrm{mgl}^{-1}$ at a dilution of $10^{-2}$ and from $0.73 \mathrm{mg} \mathrm{l}^{-2}$ at a dilution of $10^{-1}$ (Fig. 2). A similar sensitivity was found for the ova (from $0.73 \mathrm{mg} \mathrm{l}^{-1}$ ) and a higher sensitivity for fertilization (from $0.08 \mathrm{mg} \mathrm{1}^{-1}$ ).

$\mathrm{KCN}$ did not seem to be toxic at concentrations up to $1 \mathrm{mg}^{-1}$ for ova or sperm diluted at $10^{-1}$ (Fig. 3). Sperm diluted at $10^{-2}$ was sensitive to a concentration of $1 \mathrm{mg} \mathrm{l}^{-\mathrm{I}}$. In comparison, a negative effect was seen during fertilization when the concentration of $\mathrm{KCN}$ was as low as $0.001 \mathrm{mg} \mathrm{l}^{-1}$.

At a concentration of $1 \mathrm{mgl}^{-1}$; mercury significantly decreased $(P<0.005)$ the fertilizing ability of sperm at $10^{-1}$ dilution rate, but not ovum fertilizability (Fig. 4). At a dilution rate of $10^{-2}$, mercury was toxic for sperm from $0.05 \mathrm{mg} \mathrm{l}^{-1}$. The fertilization test showed a slight decrease in the fertilization rate when the concentration of $\mathrm{Hg}$ increased, but the differences were not significant. It should be noted that ovum quality was mediocre.

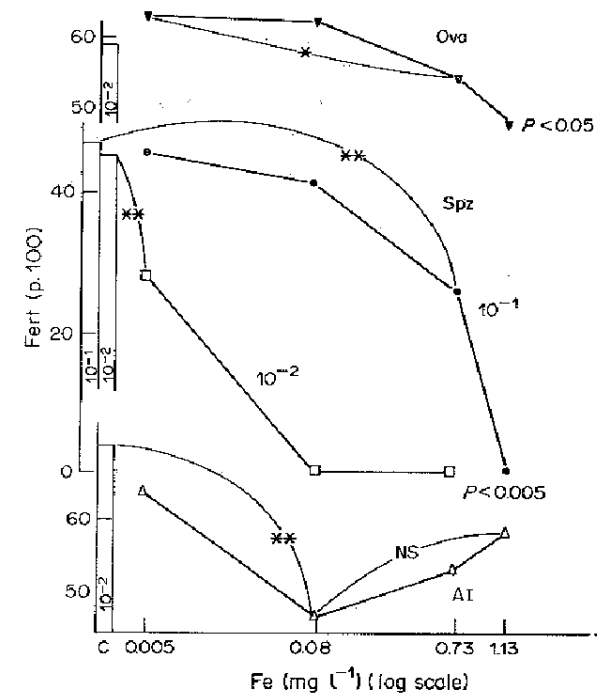

Fig. 2. Effect of iron on rainbow trout gametes. Same legend as Fig. 1 . 


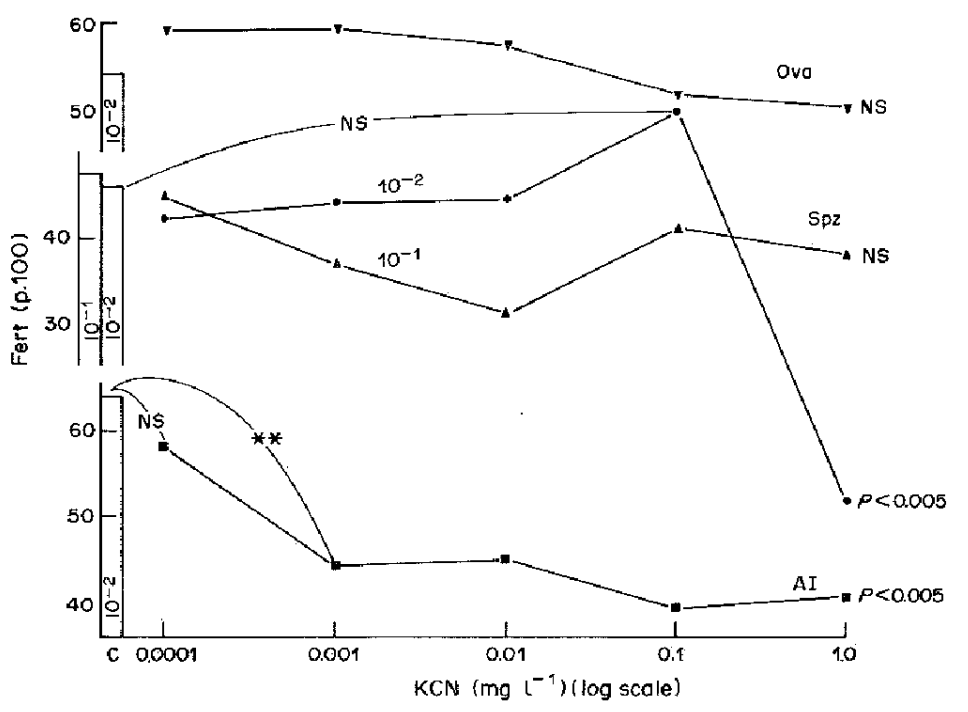

Fig. 3. Effect of cyanide on rainbow trout gametes. Same legend as Fig. 1.

Zinc at a concentration of $20 \mathrm{mg}^{-1}$ had no effect on either the ova or the sperm diluted at $10^{-1}$ but it reduced the fertilizing ability of sperm diluted at $10^{-2}$ (Fig. 5). The observed differences in the fertilization test were not significant.

Within the range of concentrations tested (from 0 to $\left.5 \mathrm{mg}^{-1}\right)$, copper had no toxic effect on gametes but there was a significant increase $(P<0.05)$ in the fertilization rate when the ID contained 0.5 and $5 \mathrm{mg} \mathrm{l}^{-1}$ of copper (Fig. 6).

\section{DISCUSSION}

The results of the present study show that there are very wide differences in the toxicity of the different substances tested and that ova and sperm, or the two during insemination, responded differently to the same chemical. $\mathrm{Cr}, \mathrm{Fe}$ and KCN seemed to be more toxic than the others, while Cu had a rather favorable effect on fertilization. Generally, prolonged $40-\mathrm{min}$ exposure was more damaging to spermatozoa than to
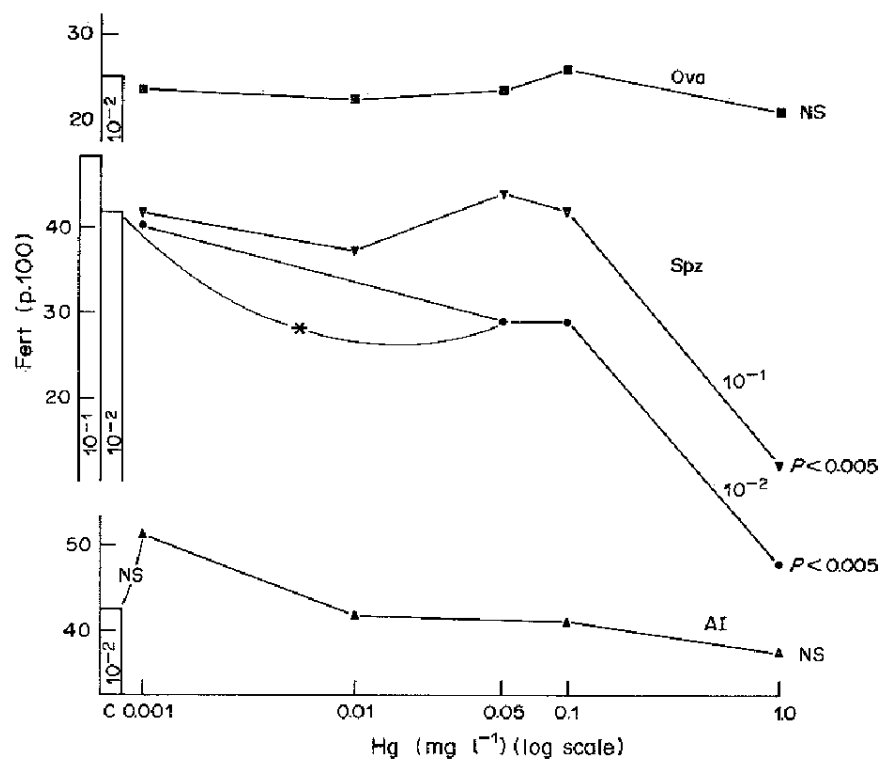

Fig. 4. Effect of mercury on rainbow trout gametes. Same legend as Fig. 1. 


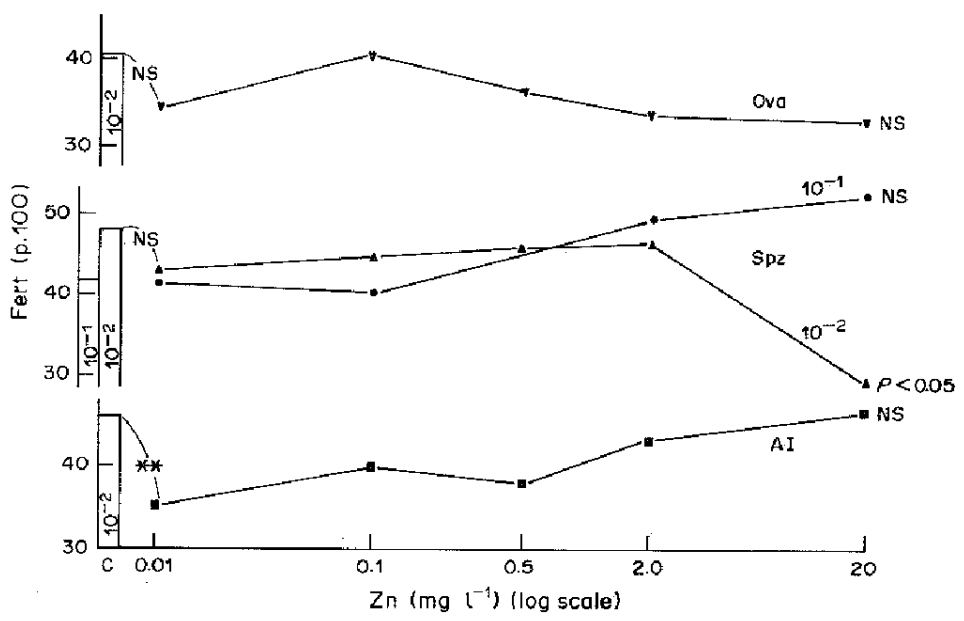

Fig. 5. Effect of zine on rainbow trout gametes. Same legend as Fig. 1.

ova, the latter in our experimental conditions being sensitive only to $\mathrm{Fe}$. The dilution rate was also an important factor, high dilution leading to greater sperm vulnerability. In this study, the unfavorable effects of dilution were probably related to the protective influence of the seminal fluid on spermatozoa (Billard, 1982, 1983). In the case of high dilution, the reduction of the number of spermatozoa per ova was more dramatic in the treated groups since some spermatozoa were injured. During the insemination tests when the gametes were put into contact simultaneously with metals for a short time, we noticed a high sensitivity to chromium and iron more similar to that in spermatozoa than to that in ova. The effects of cyanide were more marked during the insemination test than during sperm exposure; this may be due to the fact that spermatozoa are motile during insemination and therefore more sensitive to cyanide.

Gamete sensitivity to several metals tested in this experiment appeared to be very different from those reported for other developmental stages in trout and other salmonids. The fact that copper seemed to have little effect has already been reported by Shaw and Brown (1971) (no effect at a concentration of $1 \mathrm{mgl}^{-1}$ ). However; copper appeared to be much more toxic during embryogenesis and early developmental stages, minimal acceptable toxic concentrations (MATC) of $9.5-17.4 \mu \mathrm{g} \mathrm{l}^{-1}$ (McKim and Benoit; 1974) being reported for longer periods of exposure (90 days) than ours. Olson and Marking (1975) have already reported for the same species that a pesticide was less toxic to eggs than to early stages. The harmful effect of copper noted in Lepomis macrochirus after 22-month exposure appeared at $162 \mu 1 \mathrm{I}^{-1}$ (Benoit, 1975). The MATC in Pimephales promelas, estimated from the fertilization of females exposed to copper, is $32 \mu \mathrm{g} \mathrm{I}^{-1}$ (Pickering et al, 1977).

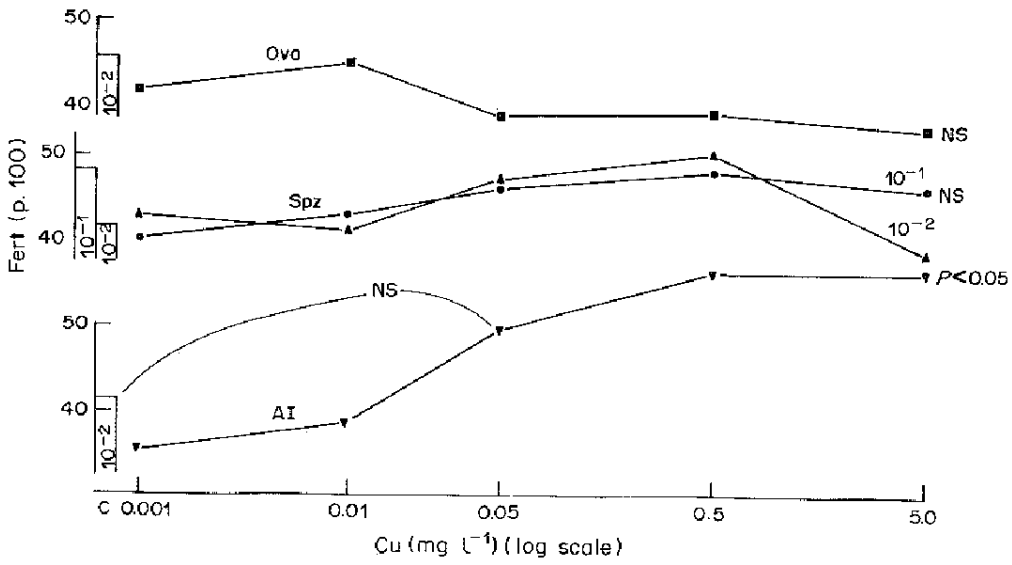

Fig. 6. Effect of copper on rainbow trout gametes. Same legend as Fig. 1. 
Table 1. Concentration (mg $\mathbf{1}^{-5}$ ) at which metals affect ovum or sperm fertility after independent (sperm-ovum) or simultaneous (artificial insemination: AI) exposure

\begin{tabular}{lccccccc}
\hline Effect on: & Dilution & $\mathrm{Cr}$ & $\mathrm{Fe}$ & $\mathrm{KCN}$ & $\mathrm{Hg}$ & $\mathrm{Zn}$ & $\mathrm{Cu}$ \\
\hline Ovum & $10^{-2}$ & $>1$ & 0.73 & $>1$ & $>1$ & $>20$ & $>5$ \\
Sperm & $\left\{10^{-1}\right.$ & $<0.005$ & 0.73 & $>1$ & 1 & $>20$ & $>5$ \\
Insemination & $10^{-2}$ & $<0.005$ & $<0.005$ & 1 & 0.05 & 20 & $>5$ \\
$10^{-7}$ & $<0.005$ & 0.08 & 0.001 & $>1$ & $>20$ & $<0.01$ \\
\hline
\end{tabular}

As regards zinc, the early stages also seem to be more sensitive than the gametes (with the same previous reservations concerning exposure). In the present study, early signis of toxicity appeared on spermatozoa at $20 \mathrm{mg}^{-1}$, while the embryos and early stages are much more sensitive (MATC: $0.5-1.3 \mathrm{mg} \mathrm{l}^{-1}$ in Salvelinis; McKim, 1977). However, Kodama et al. (1982) detected a direct zinc effect on salmon eggs which lost $80 \%$ of their elasticity after exposure to concentrations of $1.25 \mathrm{mg} \mathrm{l}^{-1}$ for $2 \mathrm{~h}$. The type of zinc cytotoxicity emphasized by these authors was not found in the present experiment on spermatozoa. In rainbow trout, the cough response occurred at $40 \mathrm{mgl}^{-1}$ (Hughes and Adeney, 1977).

Mereuric chloride $\left(\mathrm{HgCl}_{2}\right)$ was not toxic to sperm at $0.1 \mathrm{mg} \mathrm{l}^{-1} \mathrm{Hg}$ but became toxic at $1 \mathrm{mg} \mathrm{l}^{-1}$; this is lower than the concentration reported in $S$. fontinalis showing a cough response to $3 \mathrm{~g} \mathrm{l}^{-1}$ of $\mathrm{HgCl}_{2}$ (Drummond et al., 1974). The MATC in the same species is $0.29-0.93 \mu \mathrm{g}^{-1}$ of $\mathrm{Hg}$ (McKim et al., 1976). A concentration of $1 \mathrm{mg}^{-1}$ of phenylmercuric hydroxide is highly toxic to roach (Lindhal and Hill, 1970)

KCN was only very slightly toxic to sperm but was toxic after insemination when the sperm was exposed to the chemical for only a short time but was motile during that time. Toxicity as low as $0.01 \mathrm{mg} \mathrm{l}^{-1}$ has been reported for $\mathrm{KCN}$ during vitellogenesis in rainbow trout (Lesniak and Ruby, 1982).

Iron in solution $\left(0.08-0.73 \mathrm{mg} \mathrm{l}^{-1}\right)$ was toxic to sperm and in the insemination test; this result was of the same order of magnitude as the chronic concentration of $12 \mathrm{mg} \mathrm{l}^{-1}$ of iron which affects the survival and growth of $S$. fontinalis (Sykora et al, 1975).

Sperm sensitivity to chromium (at least $5 \mu \mathrm{gl}^{-1}$ ) was stronger according to our results than that reported for early stages in S. fontinalis; MATC it the latter ranged between 200 and $350 \mu \mathrm{gl}^{-1}$ (Benoit, 1976 ) and between 51 and $105 \mu \mathrm{gl}^{-1}$ (Sauter et al, 1977). The three tests used reflect different physiological situations, which would explain the divergencies observed. Ova that stand high concentrations of chemicals without loss of fertility thus seem to be relatively well protected, perhaps by the acidic mucopolysaccharide layer of the shell which binds metals such as copper (McKim and Benoit, 1974) and cadmium (Beattie and Pascoe, 1978), although this was not confirmed by Rombourg and Garside (1983). On the contrary, spermatozoa appeared to be more sensitive to prolonged exposure but the effect measured during this test was only a simple cytotoxic one and did not reflect any influence on motility, as in the case of the insemination test. In the latter test, the effect was additive, being the accumulative result of a cytotoxic effect on ova and spermatozoa as well as an effect on motility and the energetic mechanism triggered. Since the cytotoxic effect on the ova was slight, the effect on the cytotoxicity and motility of the spermatozoa was proportionally greater. Also, at the time of fertilization, especially during sperm penetration of the ova through the micropyle and during the cortical reaction, water (and chemicals in this case) may enter the ova. It is possible that some metals have a tanning effect on the shell, limiting their entry into the ova and explaining why, in some cases, iron toxicity is reduced when the concentrate increases. The paradoxical effect on the insemination test of copper, which induced a slight increase in survival rate, may be due to an effect that protects the eggs against fungus. This insemination test could be used routinely to estimate the effects of chemicals on a stage of the life-cycle of fish that has been little studied up to now. Sperm exposure and insemination without washing the sperm before insemination can also be combined.

Acknowledgements-This work was carried out under grants from EEC-INRA and from "Secrétariat d'Etat à l'Environment-INRA" No. 8340. We wish to thank Ms A. Daifuku for editing the English manuscript.

\section{RFFERENCES}

Beattie J. H. and Pascoe D. (1978) Cadmium uptake by rainbow trout, Salmo gairdneri eggs and alevins. J. Fish Biol. 13, 631-637.

Benoit D. A. (1975) Chronic effects of copper on survival, growth, and reproduction of the bluesgill. Trans. Am. Fish. Soc. 104, 353-358.

Benoit D. A. (1976) Chronic effects of hexavalant chromium on brook trout (Salvelinus fontinalis) and rainbow trout (Salmo gairdneri). Water Res. 10, 497-500.

Billard R. (1977) Utilisation d'un système Tris-glycocolle pour tamponner le dilueur d'insémination de truite. Bull. fr. Pisic. 264, 102-112.

Billard R. (1978) Effects of heat pollution and organochlorinated pesticides on fish reproduction. Final report on research sponsored under the fish environmental research programme, Brussels.

Billard R. (1982) Influence de sediments argileux incorporés au milieu d'insémination sur le succés de la fécondation chez la truite arc-en-ciel (Salmo gairdneri) Water Res. 16, 725-728.

Billard R. (1983) Effects of coelomic and seminal fluids and various saline diluents on the fertilizing ability of spermatozoa in the rainbow trout, Salmo gairdneri. J. Reprad. Fert. 68, 77-84.

Billard R. and Gillet C. (1981) Vieillissement des ovules et potentialisation par la température des effets des micro- 
poliuants du milieu aqueux sur les gamètes chez la truite. Cah. Lab. Montereau 12, 34-42.

Billard R. and Jaldbert B. (1974) I'inséminätion artificielle de la truite Salmo gairdheri Richardson. II

Comparaison des effets de différents dilueurs sur la conservation de la fertilité des gamètes avant et après insémination. Ann. Biol. anim. Biochem. Biophys. 14, 601-610.

Billard R, Cazin J. C, Dequidt J., Erb F. and Colein P. (1978) Toxicité du pyralène 3010 sur les ovules et les spermatozoides de truites arc-en-ciel avant et pendant l'ịnsémination. Bull. fr. Pisic. 270, 238-249.

Drummond R. A., Olson G. F. and Batterman A. R. (1974) Cough response and uptake of mercury by brook trout, Salvelinus fontinalis, exposed to mercuric compounds al different hydrogen-ion concentrations. Trans. Am. Fish. Soc. 103, 244-249.

EIFAC (1975) Report on fish toxicity testing procedurcs. EIFAC Technical Paper No. 24, FAO, Rome.

Gillet $\mathrm{Ch}$. and Rouband P. (1983) Influence sur la survie jusquẩ eclosion des embryons de carpe commune $(C y$ prinus carpio $\mathrm{L}$.) apres traitement, pendant la fécondation et le développement précoce, par le carbendazime, un fongicide antimitotique de synihèse. Waser Res. 17, $1343-1348$

Hughes G. and Adeney R. J. (1977) The effects of zinc on the cardiac and ventilatory rhythm of rainbow trout (Solmo gairdneri, Richardson) and theit responses to enviromment hypoxia. Water Res. 11, 1069-1077.

Jaoul A. and Roubaud P. (1982) Résistance de l'oeuf de carpe commune (Cyprinus carpio L. Cypinidae) à des choos thermiques chauds ou froids. Can. J. Zool. 60 , 3409-3419.

Kodama M., Ogala T. and Yamamori K. (1982) Acute toxicity of zinc to rainbow trout Salmo gairdneri. Bull. Jap. Soc. seient. Fish. 48, 1055-1058.

Lesniak $\Lambda$. and Ruby M. (1982) Histological and cquatitative effects of subiethal cyanide exposure on oocyte development in rainbow trout. Archs enpir. contam. Toxic. 11, 343-352

Lindahl P. E. and Hill C. E. B. (1970) Effect of short-term cxposure of Leuciscus rutilus L. (Pisces) to phenylmercuric hydroxide. Oikos 21, 267-275.

Mckim J. M. (1977) Evaluation of tests with early life stages of fish for predicting long-term toxicity. $J$. Fish. Res. Bd Can. 34, $1148-1154$

McKim J. M. and Benoit D. A. (1974) Duration of toxicity lests for establishing "no effect" concentrations for copper with brook trout (Salvelinus fontinalis). J. Fish. Res. Bd Can. 31, 449-452.

MoKin J. M., Anderson R. L., Benoit D. A., Spehar R. L. and Stokes G.N. (1976) Effects of pollution on freshwater fish. J. Wat. Pollut. Control Fed. 48, 1544-1620.

Olson L. E. and Marking L. L. (1975) Toxicity of four toxicants to green eggs of salmonids. Progue Fish. Cult. 37, 143-147.

Pickering Q., Brungs W. and Gast M. (1977) Effect of exposure time and copper concentration on reproduction of the fathead minnow (Pimephales promelas). Water Res. 11, 1079-1083

Rombough P. J. and Garside E. T. (1983) The influence of the zona radiata on the toxicity and uptake of cadmium in embryos of Atlantic salmon (Salmo salar). Can. J. Zool. 61, 2338-2343.

Sauter S., Brixton S., Macek K. J. and Petroceli S. R. (1977). Effects of continuous exposure to lead, chromium, copper and cadmium on eggs and fry of selected freshwater fish. U.S. Environmental Protection Agency, Ecology Research Series

Shaw T. L. and Brown V. M. (1971) Heavy metals and the fertilization of rainbow trout eggs. Natire 230, 251.

Sykora J. L., Smith E. J., Synak M. and Shapiro M. A (1975) Some observations on spawming of brood trout (Salvelinus fontiralis, Mitchilly in lime neutratized iron hydroxide suspensions. Water Res. 9, 451-458. 